\title{
Changes in Physiological Parameters of Bullocks during Agricultural Field Operations and their Field Efficiency in Mountain Agriculture
}

\author{
Archana Bhatt*, B. S. Meena and C. G. Shashank \\ National Dairy Research Institute, Karnal, India \\ *Corresponding author
}

\section{A B S T R A C T}

\begin{tabular}{|c|}
\hline Keywords \\
\hline $\begin{array}{l}\text { Bullocks, Field } \\
\text { efficiency, } \\
\text { Mountain } \\
\text { agriculture, Field } \\
\text { performance, } \\
\text { Physiological } \\
\text { parameters }\end{array}$ \\
\hline Article Info \\
\hline $\begin{array}{l}\text { Accepted: } \\
22 \text { March } 2020 \\
\text { Available Online: } \\
10 \text { April } 2020\end{array}$ \\
\hline
\end{tabular}

Uttarakhand is one of the hill states of India that lies in the Central Himalayan region wherein agriculture \& livestock form the basis of subsistent livelihood for the population. Livestock is an integral part of mountain agriculture; moreover, bullocks are considered as the lifeline of farming in the hilly terrain as they prepare the field for carrying various agricultural activities. Therefore, a study was done to measure the field performance of bullocks in terms of field efficiency, work hours/day and work rate/ha and data was taken from 40 pairs of bullocks at the time of ploughing. Apart from that, data was taken through manual measurement on respiration rate, pulse rate and rectal temperature before and after one hour of ploughing. Animal body weight was also measured manually and Temperature Humidity Index (THI) was also taken of the area with the help of hygrometer and concerned formula. Body weight of the bullocks came up to be $176.95 \pm 1.848(\mathrm{~kg})$ and THI came at an average of $66.23 \pm 0.742$. The before and after values after one hour of field work came from $37.91 \pm 0.039$ to $38.67 \pm 0.035 ; 22.72 \pm 0.202$ to $34.28 \pm 0.26$ and $57.12 \pm 0.347$ to $76.9 \pm 0.361$ for rectal temperature, respiration rate and pulse rate respectively. Average productive work hours/day, total work hours/day, speed $(\mathrm{km} / \mathrm{hr})$ and work rate $(\mathrm{ha} / \mathrm{hr})$ were found to be $5.35 \pm 0.093,6.19 \pm 0.103,1.88 \pm 0.029$ and $0.022 \pm 0.0009$ respectively. Field efficiency of the bullocks was found to be $86.5 \pm 0.573$ percent.

\section{Introduction}

Draught animals are an indispensable part of mountain agriculture and without them in the picture, farming in the mountains will lose its existence. Mechanical energy is still less accessible and less affordable to be used for agricultural operations in the hills. Animal powered energy is the most feasible and better alternative in context of mountain agriculture. As mechanized agriculture based on fossil fuels is not feasible in the mountains because of the topographic specificities; animals and manual tools are the most applicable and reliable source of power for agricultural operations. The use of draught animals with improved farm machines and implements with increased efficiency and annual utilization not only helps in reducing human drudgery but also aids in making multiple cropping system work. To make full and effective use of the draught animal power, it is important to have an idea on their field performance in the hilly regions. There have 
been very less studies that measure the performance of draught animals at field level among farmers. The present study aimed at knowing about the work performance of bullocks in field operation. Effect of work on physiological parameters of bullocks was also measured along with parameters associated with work performance.

\section{Materials and Methods}

Present study was conducted in the hilly state of Northern India, Uttarakhand on account of its highest population of indigenous male cattle among northern hill states (Livestock Census, 2012). For measuring field performance, data was collected from 40 bullock pairs; 10 from each district randomly selected and various parameters associated with the performance of draught animals were also taken into account i.e. body weight, physiological parameters, speed of animal, work rate and productive hours. Data was collected during October-November when ploughing for winter season crops was done. Bodyweight of the animals was calculated by using the Schaeffer's formula.

$\mathrm{W}=\mathrm{LG}^{2} / 300$

Where, $\mathrm{L}$ is the length of the animal from point of shoulder to point of buttocks in inches

$\mathrm{G}$ is the chest girth of the animal in inches

$\mathrm{W}$ is the weight of the animal expressed in pounds

Field area was measured using inch tape and the length covered per unit time was also noted to calculate speed. Work rate was calculated as area covered per unit time. Field efficiency was measured with the help of concerned formula and was expressed in percentage.
Field efficiency $=$ Net productive time $\div$ Total time of operation

Rectal temperature of bullock pair was taken before ploughing and after one hour of ploughing using a digital thermometer. Respiration rate of bullock pair was taken before ploughing and after one hour of ploughing. It was measured manually by the diaphragm movement of the animal or counting breaths per minute. Pulse rate of bullock pair was taken before ploughing and after one hour of ploughing. It was measured manually by counting the pulse per minute via examining the nerve in the tail of the animal. Temperature Humidity Index (THI) was measured manually with the use of Dry and Wet Bulb Hygrometer by noting down dry and wet bulb temperature two times in a day i.e. 7 a.m. and 2.30 p.m. After that concerned formula was used to calculate THI of the area under investigation.

$\mathrm{THI}=0.72\left(\mathrm{~T}_{\mathrm{db}}+\mathrm{T}_{\mathrm{wb}}\right)+40.6$

$\left(\mathrm{T}_{\mathrm{db}}=\right.$ dry bulb temp., $\mathrm{T}_{\mathrm{wb}}=$ wet bulb temp. $)$

\section{Results and Discussion}

\section{Changes in physiological parameters}

Results from the study indicated that there was an increase in the physiological parameters under study after field operations. Data was noted down on three parameters i.e. Rectal temperature, Respiration rate and Pulse rate before and after ploughing in the field for one hour.

\section{Rectal temperature}

Normal range of rectal temperature for bullocks ranges from $38^{\circ} \mathrm{C}$ to $39.33^{\circ} \mathrm{C}$. Average rectal temperature of bullock pair was found to be $37.91 \pm 0.039{ }^{\circ} \mathrm{C}$ before ploughing and it ranged from $37.2^{\circ} \mathrm{C}$ to $38.3^{\circ} \mathrm{C}$. After one hour of ploughing, the 
average temperature rose to $38.67 \pm 0.035{ }^{\circ} \mathrm{C}$ while it ranged from 38.2 to $39^{\circ} \mathrm{C}$. It was found that temperature increased with work but remained in the normal range.

\section{Respiration rate}

Results were similar as in case of rectal temperature with increased breaths per minute after field work. Respiration rate before ploughing was found to be $22.72 \pm 0.202$ breaths per minute while it ranged from 21 to 26 breaths per minute. After one hour of ploughing, respiration rate increased to $34.28 \pm 0.26$ while it ranged from 31 to 39 breaths per minute. It was found that increased respiration rate was higher than the normal range of respiration rate i.e. 10 to 30 breaths per minute.

\section{Pulse rate}

The range of pulse rate before ploughing came as 52 to 64 pulses per minute and the average pulse rate was recorded as 57.12 \pm 0.347 . Pulse rate after ploughing increased to a much higher value i.e. $76.9 \pm 0.361$ and ranged from 72 to 80 pulse per minute that was quite higher than the normal range which ranges from 60 to 70 pulse per minute.

It was evident from the results that there was an increase in all the physiological parameters after working in the field. The increase in rectal temperature can be associated with heat produced due to exercise leading to muscle contraction during field work. The results were in line with findings reported by Yadav and Dhaka (2001) that reported increase in rectal temperature from 100.8 to 101.9 after two hours of cart pulling. Increase in pulse rate can be attributed to increase in metabolic rate to provide energy to muscles for working in the field. Similar results were also reported by Yadav and Dhaka (2001), Yadav and Chopra (1999) and Sree Kumar and Thomas (1990) among various breeds of cattle in India. The results are briefly presented in table 1 .

\section{Temperature Humidity Index (THI)}

Temperature humidity Index for cattle to work in an environment free from heat stress lies below the value of 73. In the present study, average THI was found to be $66.23 \pm 0.742$ and the highest range was 72 ; which shows that animals were not working under heat stress. This is because the study was taken during October to November when the temperature starts to go down and the animal can perform well in the field operations without heat stress. The results of the study are shown in following Table 2.

Table.1 Changes in physiological parameters after ploughing

\begin{tabular}{|l|c|c|c|}
\hline Particulars & $\begin{array}{c}\text { Before ploughing } \\
\text { (Mean } \pm \text { SEM) }\end{array}$ & $\begin{array}{c}\text { After ploughing } \\
\text { (Mean } \pm \text { SEM) }\end{array}$ & $\begin{array}{c}\text { Normal } \\
\text { range }\end{array}$ \\
\hline $\begin{array}{l}\text { Rectal } \\
\text { temperature }\left({ }^{\circ} \mathbf{C}\right)\end{array}$ & $\begin{array}{c}37.91 \pm 0.039 \\
\text { (Range: } 37.2 \text { to } 38.3)\end{array}$ & $\begin{array}{c}38.67 \pm 0.035 \\
\text { (Range: } 38.2 \text { to } 39)\end{array}$ & 38 to 39.33 \\
\hline $\begin{array}{l}\text { Respiration rate } \\
\text { (Breaths/minute) }\end{array}$ & $\begin{array}{c}22.72 \pm 0.202 \\
\text { Range: }(21 \text { to } 26)\end{array}$ & $\begin{array}{c}34.28 \pm 0.26 \\
\text { Range: }(31 \text { to } 39)\end{array}$ & 10 to 30 \\
\hline $\begin{array}{l}\text { Pulse rate } \\
\text { (Pulse/minute) }\end{array}$ & $\begin{array}{c}57.12 \pm 0.347 \\
\text { Range: }(52 \text { to } 64)\end{array}$ & $\begin{array}{c}76.9 \pm 0.361 \\
\text { Range: }(72 \text { to } 82)\end{array}$ & 60 to 70 \\
\hline
\end{tabular}


Table.2 Temperature humidity index of study area

\begin{tabular}{|l|c|c|c|}
\hline Temperature & Mean \pm SEM & Range & Normal Range \\
\cline { 2 - 4 } Humidity Index (THI) & $66.23 \pm 0.742$ & 57.2 to 72 & $<73$ \\
\hline
\end{tabular}

Table.3 Field performance of bullocks

\begin{tabular}{|l|c|c|}
\hline Particulars & Mean \pm SEM & Range \\
\hline Body weight (Kg) & $176.95 \pm 1.848$ & 147.87 to 201.23 \\
\hline Productive work hours/day & $5.35 \pm 0.093$ & 4.50 to 7.25 \\
\hline Total work hours/day & $6.19 \pm 0.103$ & 5.00 to 8.00 \\
\hline Speed (km/hour) & $1.88 \pm 0.029$ & 1.50 to 2.00 \\
\hline $\begin{array}{l}\text { Work rate or Field capacity } \\
\text { (ha/hour) }\end{array}$ & $0.022 \pm 0.0009$ & 0.02 to 0.04 \\
\hline Field efficiency (\%) & $86.50 \pm 0.573$ & 78.57 to 95.00 \\
\hline
\end{tabular}

\section{Field performance of bullocks}

Field performance of bullocks was measured through studying certain parameters that are given in table 3. It was found that bullocks in study area belonged to non-descript indigenous breeds and were of short stature. Bullocks in the study area were having lesser body weight compared to other indigenous bullock breeds in the plains.

One pair of bullocks worked for an average of 5.35 productive hours in a day in the field while the range varied from 4.5 to 7.25 hours a day. Field capacity i.e. work rate of bullock pair was found to be 0.022 ha area ploughed per hour that was similar to study done by Makki (2013) in Sudan which reported field capacities lying between 0.06 and $0.1 \mathrm{ha} / \mathrm{hr}$. Another study in Ethiopia by Wakayo and Abayneh (2007) also reported that a pair of oxen worked for 7.60 hours in a day and ploughed an area of 0.38 hectare per day that was higher than the current study which implies better work performance of oxen in Africa.

Field efficiency of the bullock pairs ranged from 78.57percent to $95.00 \%$ while average field efficiency was 86.50 percent. It was found that majority of bullock pairs were having higher level of efficiency when compared to study done by Makki and Manzool (2013) in African countries that reported field efficiency lying between 70.00 to 80.00 percent and not higher than that. Pundir et al., (2014) in a study conducted in Uttarakhand also reported similar finding on weight of bullock i.e. average weight of bullocks in the region was found to range between 110 to $135 \mathrm{~kg}$ that was little less than reported in current study.

In conclusion, bullocks form the backbone of hill farming and are an integral part of mountain agriculture. But with mechanization and increased demand of crossbred milch cattle breeds coupled with migration and fodder scarcity in the mountain region, their role is declining and not acknowledged. On account of their importance as agricultural workforce, it is important to have know-how on their field performance so that suggestions for improvement can be made. Results generated on performance of bullocks will certainly help in formulating a strategy for animal breeders and policy makers with regards to draught breed improvement. 


\section{Acknowledgement}

Authors are thankful to Director, ICARNDRI, Karnal for providing facilities for conduction of the research work.

\section{References}

Anonymous. 2012. 19 ${ }^{\text {th }}$ Livestock Census2012, All India Report. Ministry of Agriculture Department of Animal Husbandry, Dairying and Fisheries, GOI, KrishiBhawan, New Delhi.

Makki E.K. 2013. Husbandry, working practices and field performance when using draught oxen in land preparation in Shambat, Nile valley, Sudan. Trop. Anim. Health. Prod., 46: 145-151.

Makki, E.K. and Manzool, S.A. 2013. Relationship between management and field performance of draught animals used for land preparation. An example from South Kordofan State, Suda. Global Advanced Research Journal of Agricultural Science. 2(3): 80-87.

Pundir, R.K., Singh, P.K., Neelkant, Sharma, D., Kumar, S., Tiwari, R., Singh, C.V. and Prakash, B. 2014. Characterization and evaluation of Hill cattle of Garhwal region of Uttarakhand, India. Indian $J$. Anim. Res. 48(4): 322-328
Sree Kumar D. and Thomas, C.K. 1990. Draught efficiency and thermal strain of Kangayam and Jersey-Red Sindhi crossbred bullocks in hot humid tropics. Indian J. Anim. Sci. 60: 582-586.

Urga, B. and Abayneh, T. 2007. Study on management practices and work associated health problems of draught oxen around Debreberhan, Central Ethiopia. Livestock Research for Rural Development. 19 (https://www.researchgate.net/publicati on/230646215 Study on management practices and work associated _health_problems_of_draught_oxen_ar ound_Debreberhan_Central_Ethiopia)

Yadav, A.S. and Chopra, S.C. 1999. Estimation of draught ability parameters of Hariana breed of cattle for sustained biomass production. In proceedings: International Conference on Sustainable Animal Production Health and Environment: Future Challenges held at CCS HAU, Hisar, November 24-27, 1999.

Yadav, A.S. and Dhaka, S.S. 2001. Efficiency of sustained work and its influence on physiological responses in young bulls of Haryana cattle. Asian-Aust. J. Anim. Sci. 14(8): 1062-1066.

\section{How to cite this article:}

Archana Bhatt, B. S. Meena and Shashank, C. G. 2020. Changes in Physiological Parameters of Bullocks during Agricultural Field Operations and their Field Efficiency in Mountain Agriculture. Int.J.Curr.Microbiol.App.Sci. 9(04): 3001-3005.

doi: https://doi.org/10.20546/ijcmas.2020.904.351 